\title{
Osoby trzecie jako współczynnik efektywnej ochrony sądowej w cywilnym postępowaniu procesowym
}

\section{Wprowadzenie}

—fektywność cywilnego postępowania procesowego przekłada się na efektywEność ochrony sądowej. Parafrazując stanowisko wyrażane przez Władysława

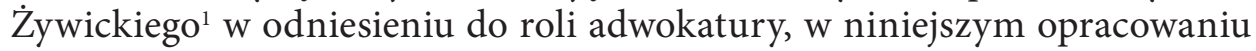
autorka dąży do wykazania i udowodnienia, że udział osób trzecich w cywilnym postępowaniu procesowym stanowi jeden z czynników mających istotny wpływ na zapewnienie efektywnej ochrony sądowej. Chociaż status tych podmiotów nie cieszy się wystarczającym zainteresowaniem w literaturze przedmiotu, nie można pomijać ich znaczenia przy omawianiu podejmowanej tematyki.

Wskazany powyżej wpływ tej kategorii osób realizuje się w zasadzie dwutorowo. Pierwszy z nich sprowadza się do udzielenia pomocy jednej ze stron procesu, co najłatwiej i najwidoczniej da się zobrazować na przykładzie instytucji interwencji ubocznej, chociaż samą tę pomoc w mojej ocenie należy określać wyłącznie jako wypadkową podjęcia decyzji o działaniu we własnym interesie, wykorzystując instytucję zasadniczo uregulowaną w przepisie art. 76 K.p.c. ${ }^{2}$ $Z$ kolei drugi $z$ nich polega na przeciwdziałaniu zachowaniom stron czy organów egzekucyjnych, które w konsekwencji mogłyby doprowadzić do wypaczenia

\footnotetext{
* Mgr Kinga Dróżdż - Doktorantka w Katedrze Postępowania Cywilnego, Katolicki Uniwersytet Lubelski Jana Pawła II, adwokat, członek Izby Adwokackiej w Warszawie; e-mail: kingamagdalenadrozdz@gmail.com.

${ }^{1}$ W. Żywicki i in., Adwokatura jako współczynnik wymiaru sprawiedliwości, Palestra 1959, nr 7-8, s. 19-38.

${ }^{2}$ Ustawa z dnia 17 listopada 1964 r. Kodeks postępowania cywilnego, t.j. Dz. U. z 2016 r., poz. 1822 ze zm.
} 
istoty całego postępowania cywilnego. Realizacja celu postępowania cywilnego, polegająca na zapewnieniu odpowiedniej ochrony prawnej tym podmiotom, które jej poszukują ${ }^{3}$, nie jest przeprowadzana w sposób bezwzględny.

Zanim jednak przejdę do omówienia wpływu udziału osób trzecich na zapewnienie efektywnej ochrony sądowej, przybliżę definicję samej osoby trzeciej. W tym zakresie przeprowadzona przeze mnie analiza prowadzi do wniosku, że polski ustawodawca w Kodeksie postępowania cywilnego niezwykle precyzyjnie i konsekwentnie posługuje się tym pojęciem, w szczególności w odniesieniu do podmiotów biorących udział w sprawie cywilnej. Na potrzeby niniejszego opracowania wystarczające wydaje się wskazanie, że generalnie osobą trzecią nie jest strona postepowania ani też potencjalna strona postępowania, $\mathrm{tj}$. podmiot, który ma zapewnioną możność wstąpienia do sprawy cywilnej w tym charakterze. Ustawodawca w odniesieniu do tego ostatniego używa pojęcia „inna osoba”. Osoba trzecia tym wyróżnia się od pozostałych uczestników niebędących powodem czy pozwanym, że działa we własnym imieniu i na własną rzecz, nie kierując się altruistycznymi pobudkami przypisywanymi - zdaje się - zwłaszcza interwenientowi ubocznemu niesamoistnemu, lecz działa z przyczyn bardziej egocentrycznych, tj. chroniąc swój interes prawny ${ }^{4}$.

${ }^{3}$ Tak cel postępowanie cywilnego rozumie F. Zedler, zob. F. Zedler, Glosa do uchwały Sadu Najwyższego z dnia 17 stycznia 2001 r., III CZP 49/00, Przegląd Sądowy 2001, nr 9, s. 129, zob. także H. Trammer, Następcza bezprzedmiotowość procesu cywilnego, Kraków 1950, s. 19, M. Sawczuk, O celach i funkcjach postępowania cywilnego procesowego i nieprocesowego (niespornego), w: Symbolae Vitoldo Broniewicz dedicatae. Księga pamiątkowa ku czci Witolda Broniewicza, red. A. Marciniak, Łódź 1998, s. 313-316, O. Jauernig, Kilka uwag o celu procesu cywilnego, Ruch Prawniczy, Ekonomiczny i Socjologiczny 1984, z. 3, s. 61-72, R. Kulski, Cele i funkcje postępowania cywilnego, w: Postępowanie rozpoznawcze w przyszłym Kodeksie postępowania cywilnego. Materiały Ogólnopolskiego Zjazdu Katedr i Zakładów Postępowania Cywilnego w Katowicach-Kocierzu (26-29 września 2013 r.), red. A. Torbus, K. Markiewicz, Warszawa 2014, s. 443-481.

${ }^{4} \mathrm{~K}$. Dróżdż, Inna osoba jako podmiot legitymowany do złożenia skargi na czynności komornika, w: Cechą sprawiedliwości jest nie krzywdzić ludzi. Księga pamiątkowa ku czci Zenona Knypla, Sopot 2017, s. 13-17, eadem, Osoba trzecia jako podmiot uprawniony do wniesienia skargi na czynności komornika, w: Środki zaskarżenia w postępowaniu egzekucyjnym. Studia i materiały, red. J. Misztal-Konecka, Sopot 2017, s. 73-82, podobnie J. Studzińska, zob. szerzej: J. Studzińska, Środki i skuteczność ochrony osób trzecich w postępowaniu cywilnym rozpoznawczym, w: Współczesne problemy postępowania cywilnego, red. A. Klich, K. Flaga-Gieruszyńska, Toruń 2015, s. 87-120, eadem, Participation of third parties in civil proceedings as a form of protection of their legal interest. Considerations in the context of legal security of these entities, $\mathrm{w}$ : The safety of the individual and of the group in private and public law - a collection of studies, red. E. Cała -Wacinkiewicz, D. Wacinkiewicz, K. Flaga-Gieruszyńska, Gorzów Wielkopolski 2015, s. 71-84, eadem, Znaczenie udziału osób trzecich w postępowaniu cywilnym rozpoznawczym, w: Role uczestników postępowań sq̨dowych - wczoraj, dziś i jutro, red. D. Gil, E. Kruk, t. 2, Lublin 2015, s. 137-163. 


\section{Udział interwenienta ubocznego}

Niewątpliwie interwenient uboczny zajmuje w cywilnym postępowaniu procesowym pozycję osoby trzeciej, skoro nie jest stroną ${ }^{5}$. Wielokrotnie jest $\mathrm{w}$ ten sposób określany przez przedstawicieli doktryny lub w orzecznictwie, chociaż ustawodawca expressis verbis w stosunku do niego nie używa tego pojęcia w dziale III tytule IV księgi pierwszej części pierwszej Kodeksu postępowania cywilnego ${ }^{6}$. Nie ma też swojego przeciwnika procesowego ${ }^{7}$. Powyższa teza odnosi się również do sytuacji, gdy zgłaszana interwencja uboczna ma charakter samoistny, ponieważ $\mathrm{w}$ dalszym ciągu taki interwenient nie jest stroną procesową, chociaż mógłby uczestniczyć w charakterze strony, gdyby przykładowo wystąpił z powództwem łącznie z powodem ${ }^{8}$. $Z$ kolei, przytaczając pogląd wyrażony przez A. Webera ${ }^{9}$ w okresie obowiązywania dawnego Kodeksu postępowania cywilnego $^{10}$, który pozostaje aktualny na tle obecnych regulacji prawnych, interwenient uboczny staje się podmiotem procesowym przez sam fakt zgłoszenia interwencji ubocznej, gdyż od tej chwili ma zapewnioną możność dokonywania czynności dopuszczalnych według stanu sprawy i od tego momentu otrzymuje zawiadomienia i orzeczenia sądu.

Zgodnie $\mathrm{z}$ art. 76 K.p.c. kto ma interes prawny w tym, aby sprawa została rozstrzygnięta na korzyść jednej ze stron, może w każdym stanie sprawy aż do

${ }^{5}$ Zob. także S. Gołąb, Interwencja uboczna, Palestra 1934, nr 9, s. 540 oraz postanowienie Sądu Najwyższego z dnia 25 listopada 2010 r., III CZ 50/10, Lex nr 1157559.

6 Zob. chociażby postanowienie Sądu Najwyższego z dnia 21 maja 2009 r., I PK 10/09, Lex nr 687069, postanowienie Sądu Apelacyjnego w Krakowie z dnia 20 października 1992 r., I ACz 367/92, Lex nr 1680360, postanowienie Sądu Apelacyjnego w Warszawie z dnia 29 października 1996 r., I ACz 1035/96, OSA 1997, z. 5, poz. 30 czy też A. Bartz, Czy w postanowieniu, rozstrzygajacem opozycje jednej ze stron przeciwko wstapieniu do sprawy interwenienta ubocznego, można także orzec o kosztach, spowodowanych opozycja?, Polski Proces Cywilny 1938, nr 16-18, s. 548.

7 Podobnie A. Weber, Czy od zgłaszającego interwencję uboczna należy stronie zasądzić koszty uwzględnionej opozycji?, Polski Proces Cywilny 1935, nr 5-6, s. 176.

${ }^{8}$ W. Głodowski, Interwencja uboczna w postępowaniu ze skargi o uchylenie wyroku sadu polubownego, w: Mediacja i arbitraż jako sposoby polubownego rozstrzygania sporów, red. D. Czura-Kalinowska, Poznań 2009, s. 234; zob. także M. Allerhand, Interwencja uboczna przed sądem polubownym, Polski Proces Cywilny 1938, nr 21-22, s. 687, J. Ignatowicz, Interwencja uboczna w sprawach o prawa stanu, Nowe Prawo 1959, nr 1, s. 29 czy też Z. Wiszniewski, Glosa do uchwały Sądu Najwyższego $z$ dnia 14 kwietnia 1960 r., 4 CO 3/60, Państwo i Prawo 1961, z. 2, s. 351.

9 A. Weber, Czy sad wydaje postanowienie o dopuszczeniu interwenienta ubocznego?, Polski Proces Cywilny 1935, nr 20, s. 633; zob. także M. Zieliński, Zawieszenie postępowania w przypadku śmierci interwenienta ubocznego. Glosa do postanowienia Sądu Apelacyjnego w Warszawie z dnia 4 sierpnia 2004 r., I ACz 969/04, Gdańskie Studia Prawnicze 2014, nr 1, s. 87 oraz A. Weber, Wpływ śmierci interwenienta ubocznego na bieg procesu, Polski Proces Cywilny 1935, nr 7-8, s. 227.

${ }^{10}$ Rozporządzenie Prezydenta Rzeczypospolitej z dnia 29 listopada 1930 r. - Kodeks postępowania cywilnego, t.j. Dz. U. z 1932 r. Nr 112, poz. 934, uwzględniające rozporządzenie Prezydenta RP z dnia 27 października 1932 r. - Prawo o sądowym postępowaniu egzekucyjnym, Dz. U. Nr 93, poz. 803. 
zamknięcia rozprawy w drugiej instancji przystąpić do tej strony (interwencja uboczna). Przesłanką dopuszczalności wstąpienia do procesu jest legitymowanie się - ubiegającego się o taki status - interesem natury prawnej tego rodzaju, by strona sporu, po której chce on uczestniczyć, wygrała proces, albowiem jego wynik w sposób bezpośredni lub pośredni oddziała na - godną ochrony - sferę prawną potencjalnego interwenienta. W tym celu ustawodawca przyznał zgłaszającemu interwencję dobrodziejstwo omawianej instytucji, by tym samym poprzez swój udział w postępowaniu w pewnym stopniu kształtował jego przebieg i poprzez to w swoisty sposób kontrolował czynności strony, do której przystępuje, z punktu widzenia celowości i merytorycznej poprawności ${ }^{11}$.

Poprzez pryzmat podjętego tematu, istotna jest w szczególności regulacja przepisu art. 79 zd. 1 K.p.c. i art. 82 K.p.c. Zgodnie z pierwszym z nich, interwenient uboczny jest uprawniony do wszelkich czynności procesowych dopuszczalnych według stanu sprawy, tj. możliwych do podjęcia na określonym etapie postępowania ${ }^{12}$. Powszechnie rolę i status omawianego podmiotu sprowadza się do udzielenia pomocy jednej ze stron procesowych poprzez dokonywanie szeregu czynności procesowych - z uwzględnieniem reguł określonych w Kodeksie postępowania cywilnego ${ }^{13}$. Jak z kolei wynika z art. 79 zd. 2 K.p.c., podejmowane przez interwenienta ubocznego zwykłego czynności procesowe nie mogą pozostawać w sprzeczności z czynnościami i oświadczeniami strony, do której przystąpił. Zgodnie z art. 82 K.p.c., interwenient uboczny nie może w stosunku do strony, do której przystąpił, podnieść zarzutu, że sprawa została rozstrzygnięta błędnie albo że strona ta prowadziła proces wadliwie, chyba że stan sprawy w chwili przystąpienia interwenienta uniemożliwił mu korzystanie ze środków obrony albo że strona umyślnie lub przez niedbalstwo nie skorzystała ze środków, które nie były interwenientowi znane.

W ocenie autorki właśnie dzięki przysporzeniu go w możność korzystania z przysługujących mu środków obrony udział interwenienta ubocznego gwarantuje bardziej efektywną ochronę sądową, realizującą się poprzez osobiste uczestnictwo w sprawie cywilnej toczącej się pomiędzy innymi osobami, i w spieraniu strony, u boku której działa, co w konsekwencji prowadzi do osiągnięcia celu procesu cywilnego w najlepszy z możliwych sposobów. Osoba trzecia, która zajmuje stanowisko interwenienta ubocznego w sprawie cywilnej, może nie tylko działać i przez to udzielać pomocy stronie, do której przystąpiła, m.in. poprzez zgłaszanie zarzutów, zaprzeczanie informacjom podanym jako uzasadnienie żądania czy też zarzutów przeciwnika procesowego strony, przy boku której

11 Postanowienie Sądu Apelacyjnego w Krakowie z dnia 4 września 2012 r., I ACz 1232/12, Lex nr 1216300 .

12 A. Zieliński, w: Kodeks postępowania cywilnego. Komentarz, red. A. Zieliński, wyd. 9, Warszawa 2017, s. 180 .

13 J. Mucha, Zawisłość sprawy w procesie cywilnym, Warszawa 2014, s. 320. 
występuje interwenient. Omawiana obrona może sprowadzać się do uzasadniania o nowe okoliczności faktyczne podniesionych żądań czy przytoczonych zarzutów powoda lub pozwanego, u boku którego działa. Wreszcie osoba trzecia ma zapewnioną możność zgłaszania: zastrzeżeń co do dostrzeżonych uchybień proceduralnych, wniosków proceduralnych, wnoszenia środków odwoławczych czy też zaskarżenia itp. Na marginesie można też wskazać, że przykładem czynności, których dotyczy przepis art. $77 \$ 2$ K.p.c., jest złożenie pisma zawierającego odpowiedź na pozew, wniosek dowodowy, wniosek o zabezpieczenie powództwa, wniosek o sporządzenie uzasadnienia orzeczenia czy też wreszcie wniosek o przywrócenie terminu z powołaniem się na okoliczności dotyczące strony. W ramach omawianego pojęcia - z uwzględnieniem ograniczeń narzuconych przez ustawodawcę interwenientowi ubocznemu - mieści się zgłoszenie wszelkich zarzutów merytorycznych i formalnych ${ }^{14}$.

Uzupełniająco można wskazać, że norma substancjalna wyrażona przepisie art. 81 K.p.c. przyznaje interwenientowi ubocznemu samoistnemu prawa współuczestnika procesu przy współuczestnictwie jednolitym. Ratio legis obecnego brzmienia tej regulacji sprowadza się do przyjęcia założenia, zgodnie z którym podmiot, który ma zostać objęty skutkiem prawomocnego wyroku po zakończeniu procesu, powinien zostać wyposażony we wszelkie uprawnienia, jakie przysługują stronom tegoż postępowania, ponieważ przyjęcie odmiennego stanowiska byłoby na tyle niekorzystne dla interwenienta ubocznego samoistnego, że wręcz dochodziłoby do pozbawienia go należytej ochrony prawnej ${ }^{15}$. Odmienny charakter ryzyka wpływu rozstrzygnięcia, jakie ma zapaść w sprawie, na sferę prawną tego podmiotu, determinuje przyznanie mu szerszych uprawnień niż interwenientowi zwykłemu ${ }^{16}$.

\section{Udział przypozwanego, który nie podejmuje decyzji o wstąpieniu do sprawy w charakterze interwenienta ubocznego}

Jednym z elementów składowych mechanizmu służącego zapewnieniu efektywnej ochrony sądowej może być także dopuszczalność sygnalizacji osobie trzeciej o toczącym się procesie, a także udzielana przez nią forma pomocy,

${ }^{14} \mathrm{~W}$. Broniewicz, Jakie zmiany w instytucjach interwencji ubocznej i przypozwania wprowadzit nowy k.p.c. $i$ kodeks cywilny?, Palestra 1966, nr 10, s. 22 oraz B. Czech, w: Kodeks postępowania cywilnego. Tom I. Komentarz. Art. 1-366, red. A. Marciniak, K. Piasecki, wyd. 7, Warszawa 2016, s. 388.

${ }_{15} \mathrm{M}$. Waligórski M, Czy interwenjent samoistny ma legitymację do wniesienia skargi o wznowienie?, Polski Proces Cywilny 1935, nr 17-18, s. 563-564.

${ }^{16}$ To zagadnienie znacznie wykracza poza ramy niniejszego opracowania, zatem autorka w tym miejscu jedynie sygnalizuje tę problematykę. 
gdy podmiot ten nie podejmuje decyzji o wstąpieniu do sprawy w charakterze interwenienta ubocznego. Służy temu instytucja przypozwania, przez co rozumie się zawiadomienie przez stronę procesową osoby trzeciej o toczącym się procesie i wezwanie jej do wzięcia w nim udziału ${ }^{17}$. Nieoddające w pełni istoty tej instytucji jest omawianie przypozwania, które sprowadza się do opisania tego środka prawnego $\mathrm{w}$ kontekście skorzystania $\mathrm{z}$ niego przez powoda lub pozwanego $\mathrm{w}$ celu ochrony swojej pozycji procesowej ${ }^{18}$. Z tego też powodu instytucja ta zostanie pokrótce omówiona poprzez pryzmat interesu prawnego osoby, która jest przypozywana.

Zgodnie z art. $84 § 1$ K.p.c. strona, której w razie niekorzystnego dla niej rozstrzygnięcia przysługiwałoby roszczenie względem osoby trzeciej albo przeciwko której osoba trzecia mogłaby wystąpić z roszczeniem, może zawiadomić taką osobę o toczącym się procesie i wezwać ją do wzięcia w nim udziału. Korzyść otrzymywana dzięki tej instytucji w zasadzie polega na przysporzeniu omawianego podmiotu w możność udziału w procesie, który toczy się pomiędzy innymi podmiotami, a przez pomoc udzieloną powodowi albo pozwanemu w dążeniu do wydania rozstrzygnięcia korzystnego dla jednego z nich - eliminację rationem kolejnego procesu ${ }^{19}$. Omawiana możność jest zagwarantowana dzięki poinformowaniu osoby trzeciej o fakcie toczenia się postępowania oraz o jego przedmiocie. Bowiem zgodnie z art. $84 \$ 2$ zd. 1 K.p.c., w tym celu, tj. w celu przypozwania, strona wnosi do sądu pismo procesowe wskazujące przyczynę wezwania i stan sprawy.

H. Pietrzkowski ${ }^{20}$ zwracał uwagę na dwa zasadnicze cele przypozwania. Poprzez pryzmat sytuacji prawno-procesowej osoby trzeciej istotny jest w szczególności pierwszy z nich, który sprowadza się do sygnalizacji osobie trzeciej o toczącej się sprawie, której to wynik może oddziaływać na jej sferę prawną, co $\mathrm{z}$ kolei daje jej podstawę do zgłoszenia przystąpienia do procesu w charakterze interwenienta ubocznego w celu wspomagania konkretnej strony procesowej ${ }^{21}$. Ratio tych przepisów polega na wezwaniu osoby trzeciej do wstąpienia do sprawy, a przez to do zapewnienia jej realnej możliwości ochrony jej własnego interesu prawnego, a nie jedynie wyrażenia własnego poglądu w przedmiocie zasadności powództwa czy też konieczności jego oddalenia jako całkowicie bezzasadnego ${ }^{22}$.

17 A. Puternicki, Przypozwanie, Gazeta Sądowa Warszawska 1933, nr 35, s. 545.

${ }_{18}$ B. Bladowski zauważa, że cel przypozwania sprowadza się do zabezpieczenia strony procesowej przed zarzutem wadliwie przeprowadzonego procesu, zob. szerzej B. Bladowski, Metodyka pracy sędziego cywilisty, Kraków 2005, s. 142.

19 A. Gołąb, Przypozwanie w procesie cywilnym (art. 84-85 k.p.c.), PPC 2012, nr 1, s. 108.

${ }^{20}$ H. Pietrzkowski, Przypozwanie, w: H. Pietrzkowski, Metodyka pracy sędziego w sprawach cywilnych, wyd. 7, Warszawa 2014, s. 223.

${ }^{21}$ Ibidem.

22 Wyrok Sądu Najwyższego z dnia 7 marca 1997 r., I PKN 27/97, OSNP 1997, nr 21, poz. 422, zob. także wyrok Sądu Najwyższego z dnia 7 lutego 1966 r., II CR 259/65, Lex nr 5938. 
Z kolei zgodnie $z$ art. $84 \$ 2$ zd. 2 K.p.c., pismo zawierające przypozwanie doręcza się niezwłocznie osobie trzeciej, która może zgłosić swe przystąpienie do strony jako interwenient uboczny. Jednakże z chwilą dokonania przypozwania, interesującemu autorkę podmiotowi nie nadaje się statusu uczestnika procesu, nie są mu przyznane prawa charakterystyczne dla tej grupy osób, a w szczególności nie jest on uprawniony do podejmowania jakichkolwiek czynności procesowych, które ma możliwość dokonywania dopiero z chwilą wstąpienia do spraw ${ }^{23}$. Otrzymuje jedynie odpis pisma wniesionego przez stronę oraz zawiadomienie o terminie najbliższej rozprawy, natomiast wszelkie dalsze doręczenia są mu dokonywane $\mathrm{w}$ razie przystąpienia do strony $\mathrm{w}$ charakterze interwenienta ubocznego, zgodnie chociażby z $\$ 130$ Regulaminu urzędowania sądów powszechnych ${ }^{24}$. Należy również podkreślić, że samo doręczenie osobie trzeciej pisma zawierającego przypozwanie nie skutkuje powstaniem interesu prawnego po jej stronie ${ }^{25}$.

Skorzystanie przez nią z możliwości wzięcia udziału w sprawie cywilnej $\mathrm{w}$ charakterze interwenienta ubocznego jest co do zasady zależne jedynie od jej uznania i woli ${ }^{26}$. Podejmując decyzję o nieskorzystaniu z tej sposobności, może ona swoją aktywność ograniczyć do udzielenia jednej ze stron procesu niezbędnych wskazówek czy też pouczeń co do czynności, które - w jej ocenie - powinny zostać przedsięwzięte ${ }^{27}$. Poprzez taką czynność, gdy udzielane przez nią wskazówki są zasadne i przy dodatkowym założeniu, że strona z nich skorzysta, omawiany podmiot przyczynia się do na zapewnienia efektywniejszej ochrony sądowej.

${ }^{23}$ B. Bladowski, Metodyka pracy sędziego cywilisty, Kraków 2005, s. 142, I. Gromska-Szuster, w: Kodeks postępowania cywilnego. Komentarz. Art. 1-366, red. H. Dolecki, T. Wiśniewski, t. 1, wyd. 2, Warszawa 2013, s. 331, zob. także orzeczenie Sądu Najwyższego z dnia 14 listopada 1958 r., CR 193/58, NP 1960, nr 6, s. 788 i wyrok Sądu Apelacyjnego w Białymstoku z dnia 25 lipca 2014 r., I ACa 236/14, Lex nr 1506665.

${ }^{24}$ Rozporządzenie Ministra Sprawiedliwości z dnia 23 grudnia 2015 r. - Regulamin urzędowania sądów powszechnych, Dz. U. poz. 2316 ze zm., zob. szerzej M. Romańska, w: Regulamin urzędowania sądów powszechnych. Komentarz, red. M. Romańska, Warszawa 2013, s. 254-256.

25 A. Czerwiński, Czy przypozwany, który zgłosił interwencję uboczną, zwolniony jest od wykazania interesu prawnego we wstapieniu do sprawy? Nowy Proces Cywilny 1933, nr 15, s. 472-474.

26 A. Czerwiński, Czy przypozwany, który zgłosił interwencję uboczną, zwolniony jest od wykazania interesu prawnego we wstapieniu do sprawy?, Nowy Proces Cywilny 1933, nr 15, s. 473, zob. także wyrok Sądu Najwyższego z dnia 7 lutego 1966 r., II CR 259/65, Lex nr 5938, wyrok Sądu Apelacyjnego w Poznaniu z dnia 18 kwietnia 2007 r., I ACa 201/07, Lex nr 446233 czy też wyrok Sądu Apelacyjnego we Wrocławiu z dnia 22 lutego 2013 r., I ACa 67/13, Lex nr 1322900.

${ }_{27}$ Zob. szerzej I. Wolwiak, Zarzuty osoby przypozwanej co do nieprawidłowego prowadzenia postępowania przez stronę wobec dokonanych pomiędzy nimi uzgodnień, Monitor Prawniczy 2015, nr 2, s. 1185-1191. 


\section{Udział interwenienta głównego}

Efektywna ochrona sądowa potrafi wykryć a następnie oprzeć się zjawisku nadużyć, w tym także nadużyć procesowych, oraz nieprawidłowemu wykonywaniu powierzonych kompetencji. Są to negatywne zjawiska procesowe, które w konsekwencji prowadzą do nieosiągnięcia celu postępowania. Aby nim zapobiec, polski ustawodawca wprowadza wręcz cały wachlarz różnorodnych regulacji. Jedną z nich są przepisy dotyczące interwencji głównej, w której podmiotem uprawnionym jest osoba trzecia. Zgodnie $z$ art. 75 K.p.c., kto występuje $\mathrm{z}$ roszczeniem o rzecz lub prawo, o które sprawa toczy się pomiędzy innymi osobami, może aż do zamknięcia rozprawy w pierwszej instancji wytoczyć powództwo o tę rzecz lub prawo przeciwko obu stronom przed sąd, w którym toczy się sprawa (interwencja główna). Skorzystanie z dobrodziejstwa tych regulacji prawnych skutkuje powstaniem zupełnie nowego procesu ${ }^{28}$.

Jak wynika z uzasadnienia wyroku Sądu Najwyższego z dnia 26 marca $2009 \mathrm{r}^{29}$, związek istniejący między powództwem już toczącym się a powództwem interwencyjnym przejawia się w płaszczyźnie podmiotowej i przedmiotowej i polega na tym, że powództwo interwencyjne toczy się w ramach podmiotów wcześniejszego powództwa, które zajmują tu rolę pozwanych, zaś przedmiot powództwa interwencyjnego nie może przekraczać granic toczącej się już sprawy. Po wytoczeniu powództwa interwencyjnego istnieją dwie różne sprawy, które mogą być połączone do wspólnego rozpoznania lub też mogą być rozpoznane oddzielnie, lecz kolejno po uprzednim zawieszeniu pierwszej toczącej się już sprawy, co pozwala uniknąć wzajemnej sprzeczności zapadających w nich rozstrzygnięciach ${ }^{30}$.

Cel i ratio legis tych instytucji sprowadza się do zapobiegania wydawania sprzecznych rozstrzygnięć ogłaszanych w postępowaniu pierwotnym a interwencyjnym, które dotyczą tej samej rzeczy lub prawa, usprawnienie i przyspieszenie dochodzenia roszczenia przysługującego osobie trzeciej, zmniejszenie kosztów działania aparatu wymiaru sprawiedliwości, czy też wreszcie - swoistą kumulację różnych żądań skierowanych przeciwko dwóm podmiotom w jednym procesie i dzięki regulacjom prawnym stanowiącym odstępstwo od zasad dotyczących właściwości miejscowej sądu - rozpoznanie dwóch spraw cywilnych przez ten sam sąd ${ }^{31}$. Dzięki powyższemu cel stawiany postępowaniu cywilnemu proceso-

\footnotetext{
${ }^{28}$ J. Korzonek, Interwencja główna w k.p.c., Głos Sądownictwa 1930, nr 12, s. 805.

${ }^{29}$ Wyrok Sądu Najwyższego z dnia 26 marca 2009 r., I CSK 415/08, Lex nr 577152.

${ }^{30}$ Istnieje możliwość oddzielnego i równoległego prowadzenia postępowania głównego i interwencyjnego, ale wydaje się, że takie działanie nie jest poprawne, biorąc pod uwagę względy ekonomii procesowej.

${ }^{31}$ I. Gromska-Szuster, w: Kodeks postępowania cywilnego. Komentarz. Art. 1-366, red. H. Dolecki, T. Wiśniewski, t. 1, wyd. 2, Warszawa 2013, s. 299, zob. także T. Wiśniewski, Ochrona prawa własności
} 
wemu zostaje osiągnięty bez konieczności rozpoznawania i rozstrzygania dwóch spraw cywilnych, prowadzonych z reguły jedna po drugiej. Tym samym udział osób trzecich jako interwenientów głównych przyczynia się do zapewnienia efektywnej ochrony sądowej.

\section{Udział osoby trzeciej korzystającej z powództwa ekscydencyjnego $z$ art. 841 K.p.c.}

Drugą z instytucji służących zapobieganiu negatywnym zjawiskom procesowym, równocześnie umożliwiających udział osób trzecich w cywilnym postępowaniu procesowym, jest powództwo ekscydencyjne z art. 841 K.p.c. Jak wynika z $\$$ 1 tego przepisu, osoba trzecia może w drodze powództwa żądać zwolnienia zajętego przedmiotu od egzekucji, jeżeli skierowanie do niego egzekucji narusza jej prawa. Podmiotem uprawnionym do skorzystania z dobrodziejstwa tej instytucji jest osoba trzecia, co wynika z literalnego brzmienia przywołanego powyżej przepisu. W orzecznictwie i literaturze wskazuje się, że generalnie jest nią podmiot niebędący stroną postępowania egzekucyjnego ${ }^{32}$. Zatem posługując się kryterium formalnym, tj. ograniczając się do zbadania samej treści tytułu wykonawczego, można wskazać, czy określona osoba może być uprawniona do skorzystania z omawianego powództwa ekscydencyjnego ${ }^{33}$. Jednocześnie należy mieć na względzie, że to podmiot wszczynający postępowanie stawia określoną osobę w pozycji strony biernej tego postępowania, co w konsekwencji oznacza, że możliwa jest sytuacja, w której dłużnikiem egzekwowanym będzie

\footnotetext{
$w$ drodze interwencji głównej, w: Krytyka prawa. Niezależne studia nad prawem. Własność, red. J. Jabłońska-Bonca, t. 1, Warszawa 2009, s. 326-327, I. Kunicki, Przesłanki zgłoszenia interwencji głównej, PS 2008, nr 3, s. 52, P. Osowy, Interwencja główna (uwagi na temat aktualności i przydatności art. 75 k.p.c.) - zarys problematyki, w: Ewolucja postępowania cywilnego wobec przemian politycznych, społecznych i gospodarczych, red. H. Dolecki, K. Flaga-Gieruszyńska, Warszawa 2009, s. 266-267.

${ }^{32}$ Tak chociażby S. Kozik, w: Kodeks postępowania cywilnego. Postępowanie zabezpieczajace i egzekucyjne. Komentarz, kier. Z. Szczurek, wyd. 4, Sopot 2013, s. 495; H. Pietrzkowski, w: Kodeks postępowania cywilnego. Komentarz. Postępowanie egzekucyjne, red. E. Ereciński, t. 4, wyd. 4, Warszawa 2012, s. 295, A. Różalska, Powództwa przeciwegzekucyjne jako środki obrony merytorycznej dłużnika. Powództwo ekscydencyjne, Problemy Egzekucji Sądowej 1996, nr 28, s. 65, M. Uliasz, Kodeks postępowania cywilnego. Komentarz, wyd. 2, Warszawa 2008, s. 1240, Z. Szczurek, Egzekucja sądowa w Polsce, kier. Z. Szczurek, Sopot 2007, s. 325, F. Zedler, Powództwo o zwolnienie od egzekucji, Warszawa 1973, s. 53-57, zob. także uchwałę Sądu Najwyższego z dnia 17 października 1995 r., III CZP 143/95, OSNC 1996, nr 2, poz. 24, wyrok Sądu Apelacyjnego w Gdańsku z dnia 7 kwietnia 1994 r., I ACr 142/94, OSA 1994, z. 6, poz. 31, orzeczenie Sądu Najwyższego z dnia 6 grudnia 1960 r., IV CR 73/60, Lex nr 1631929, a także E. Wengerek, F. Zedler, Glosa do uchwały Sądu Najwyższego $z$ dnia 7 lutego 1968 r., III CZP 89/67, OSPiKA 1970, z. 5, s. 193-197.

${ }^{33}$ D. Zawistowski, w: Kodeks postępowania cywilnego. Postępowanie zabezpieczajace i egzekucyjne. Komentarz, red. J. Gołaczyński, Warszawa 2012, s. 427.
} 
osoba, która nie figuruje w tytule wykonawczym ${ }^{34}$. O legitymacji czynnej nie decydują relacje osobiste czy też rodzinne łączące podmiot korzystający z tego środka prawnego $\mathrm{z}$ wierzycielem czy dłużnikiem ${ }^{35}$.

Tak jak i w przypadku powództwa opozycyjnego, za pośrednictwem instytucji zasadniczo uregulowanej w art. 841 K.p.c. nie realizuje się obrony formalnej, która sprowadzałaby się do podnoszenia zarzutów w przedmiocie naruszenia przepisów procesowych, które regulują przebieg postępowania egzekucyjnego ${ }^{36}$. Podstawa do wytoczenia powództwa o zwolnienie zajętego przedmiotu od egzekucji występuje wówczas, gdy w toku zajęcia zostały naruszone prawa osoby trzeciej, np. dana rzecz jest własnością tej osoby, przy czym, co podkreśla się w piśmiennictwie, chodzi o naruszenie tego rodzaju, że doszło do zajęcia takiego składnika majątkowego, z którego wierzyciel nie ma prawa zaspokoić swojej wierzytelności ${ }^{37}$. Mianowicie chodzi o brak uprawnienia wierzyciela do zaspokojenia swojej należności z zajętego przedmiotu lub prawa, chociaż $\mathrm{z}$ formalnego punktu widzenia istnieją przesłanki, które zezwalają organom egzekucyjnym na skierowanie egzekucji do zajętego przedmiotu lub prawa ${ }^{38}$. W orzecznictwie pojawił się pogląd o konieczności zawężającej wykładni zwrotu „naruszenie prawa”, użytego w przepisie art. 841 K.p.c., tj. jako sam przedmiot zabezpieczenia albo egzekucji, albowiem celem omawianego środka prawnego ma być właśnie zwolnienie od egzekucji lub poprzedzającego je zabezpieczenia ${ }^{39}$.

Jak podkreśla Sąd Najwyższy w wyroku z dnia 14 kwietnia 2011 r. $^{40}$, celem powództwa przewidzianego w art. 841 k.p.c. pozostaje zwolnienie od egzekucji

${ }_{34}$ Wyrok Sądu Apelacyjnego w Gdańsku z dnia 19 maja 2009 r., I ACa 392/09, POSAG 2010, nr 1, s. 26-36, zob. także K. Korzan, Sądowe postępowanie zabezpieczające i egzekucyjne w sprawach cywilnych, Warszawa 1986, str. 222.

${ }^{35}$ K. Dróżdż, Małżonek dłużnika jako osoba trzecia legitymowana do wytoczenia powództwa o zwolnienie zajętego przedmiotu od egzekucji sądowej, Przegląd Prawa Egzekucyjnego 2016, nr 5, s. 60, R. Kulski, w: Kodeks postępowania cywilnego. Tom III. Postępowanie nieprocesowe, w razie zaginięcia lub zniszczenia akt, zabezpieczające i egzekucyjne. Komentarz do artykułów 506-1088, red. A. Marciniak, K. Piasecki, t. 3, wyd. 5, Warszawa 2012, s. 988, T. Żyznowski, w: Kodeks postępowania cywilnego. Komentarz, red. H. Dolecki, T. Wiśniewski, t. 4, wyd. 2, Warszawa 2014, s. 368, zob. także A. Różalska, Powództwa przeciwegzekucyjne jako środki obrony merytorycznej dłużnika. Powództwo ekscydencyjne, Problemy Egzekucji Sądowej 1996, nr 28, s. 80, orzeczenie Sądu Najwyższego z dnia 8 grudnia 1951 r., C 1191/51, Państwo i Prawo 1952, nr 8-9, s. 364 i uchwałę Sądu Najwyższego z dnia 14 lutego 1955 r., I CO 83/54, OSNCK 1955, nr 3, poz. 52.

${ }^{36}$ Wyrok Sądu Apelacyjnego w Katowicach z dnia 3 października 2005 r., I ACa 553/05, Lex nr 164629.

37 Wyrok Sądu Okręgowego w Nowym Sączu z dnia 12 grudnia 2013 r., III Ca 780/13, Lex nr 1716548.

${ }^{38}$ Wyrok Sądu Najwyższego z dnia 2 marca 2016 r., V CSK 372/15, Lex nr 2023937.

39 Wyrok Sądu Najwyższego z dnia 17 kwietnia 2002 r., IV CKN 986/00, Lex nr 78368.

${ }^{40}$ Wyrok Sądu Najwyższego z dnia 14 kwietnia 2011 r., IV CSK 414/10, Lex nr 1027185. 
zajętego przedmiotu, gdy egzekucja $\mathrm{z}$ takiego przedmiotu naruszałaby prawa osoby trzeciej - niezależnie od jego jurydycznej postaci. W omawianym przepisie polski prawodawca nie wprowadził kryteriów lub innych ograniczeń w przedmiocie możności kwalifikowania określonych zdarzeń jako przejawów naruszenia praw osób trzecich, a także zrezygnował z wprowadzenia przykładowego katalogu zdarzeń, których wystąpienie mogłoby świadczyć o samym naruszeniu praw interesujących autorkę podmiotó $\mathrm{w}^{41}$. Niezasadne byłoby ich wprowadzanie. Poprzez powództwo ekscydencyjne $\mathrm{z}$ art. 841 K.p.c. postępowanie egzekucyjne uwzględnia interesy osób trzecich, które są na tyle istotne, by zagwarantować ich ochronę - nawet kosztem szybkości i sprawności egzekucji. W istocie cel omawianego powództwa sprowadza się do wyjęcia spod egzekucji, czyli ustanowienia zakazu prowadzenia egzekucji, a także uchylenia skutków zajęcia ${ }^{42}$.

Nadto należy wskazać, jak daleko idąca jest to ochrona. Mianowicie w pozwie ekscydencyjnym, a nawet przed jego złożeniem, możliwe jest złożenie wniosku o zabezpieczenie powództwa przeciwegzekucyjnego przez zawieszenie postępowania egzekucyjnego na podstawie art. $755 \$ 1$ pkt 3 K.p.c. W tym miejscu autorka zwraca uwagę na skutek, który powoduje wydanie postanowienia o zawieszeniu egzekucji, tj. zawieszenie wszelkich czynności egzekucyjnych ${ }^{43}$, $\mathrm{w}$ tym przekazania stronie czynnej postępowania egzekucyjnego należności, która została uzyskana ze sprzedaży ruchomości ${ }^{44}$. W istocie zawieszenie postępowania egzekucyjnego powoduje wstrzymanie dokonywania dalszych czynności egzekucyjnych, co nie jest równoznaczne z uchyleniem dokonanego zajęcia ${ }^{45} \mathrm{~W}$ ocenie autorki jest to doskonały przykład sytuacji, w której ustawodawca szczególnie dba o efektywność ochrony realizowanej w postępowaniu egzekucyjnym. Mianowicie nie może być ona i w istocie nie jest bezwarunkowa, nieuwzględniająca interesów osób trzecich.

41 Wyrok Sądu Najwyższego z dnia 29 listopada 2001 r., V CKN 616/00, OSNC 2002, nr 7-8, poz. 105, podobnie F. Zedler, Powództwo małżonka dłużnika o zwolnienie spod egzekucji, Państwo i Prawo 1968, z. 12, s. 1020; por. art. 574 rozporządzenia Prezydenta Rzeczypospolitej z dnia 29 listopada 1930 r. - Kodeks postępowania cywilnego, t.j. Dz. U. z 1932 r. Nr 112, poz. 934, uwzględniające rozporządzenie Prezydenta RP z dnia 27 października 1932 r. - Prawo o sądowym postępowaniu egzekucyjnym, Dz. U. Nr 93, poz. 803.

${ }^{42}$ Wyrok Sądu Apelacyjnego w Gdańsku z dnia 22 stycznia 2014 r., I ACa 318/13, Lex nr 1433773.

43 T. Żyznowski, w: Kodeks postępowania cywilnego. Komentarz, red. H. Dolecki, T. Wiśniewski, t. 4, wyd. 2, Warszawa 2014, s. 388.

${ }^{44}$ Wyrok Sądu Najwyższego z dnia 18 stycznia 1978 r., IV CR 463/77, OSNC 1978, nr 10, poz. 186.

45 F. Zedler, Projektowane zmiany przepisów o postępowaniu egzekucyjnym, w: Reforma postępowania cywilnego w świetle projektów Komisji Kodyfikacyjnej, red. K. Markiewicz, Warszawa 2011, s. 160. 


\section{Osoba trzecia jako podmiot dysponujący materiałem dowodowym}

Na zakończenie należy również wskazać, że sam termin „osoba trzecia” występuje również w przepisach regulujących postępowanie dowodowe, a ściślej w odniesieniu do podmiotu posiadającego dokument, przedmiot oględzin, czyli - najogólniej - jako podmiot dysponujący materiałem dowodowym. W tym miejscu należy zwrócić uwagę na literale brzmienie art. $187 \$ 1$ pkt 4 K.p.c., art. 246 K.p.c., art. 251 zd. 1 i 2 K.p.c., art. $254 \$ 4$ K.p.c., art. 294 K.p.c., art. $295 \$ 1$ i 2 K.p.c. i art. 296 K.p.c., art. 297 K.p.c. Szczegółowa analiza wymienionych powyżej przepisów zdecydowanie przekraczałaby ramy niniejszego opracowania. Wydaje się, że dla należytego omówienia tematu jest wystarczające ograniczenie się do wskazania, że powyższe regulacje dotyczą m. in. uprawień i obowiązków osoby trzeciej, która - jak wskazano powyżej - dysponuje materiałem dowodowym. Nie jest ona zainteresowana wyrokiem, który ma zapaść w sprawie, a $\mathrm{z}$ pewnością przynajmniej nie jest $\mathrm{z}$ tego powodu zaangażowana w daną sprawę cywilną. Należy podkreślić, że łączność tego podmiotu ze sporem ma charakter przedmiotowy w tym znaczeniu, że sam związek osoby trzeciej $\mathrm{z}$ zebranym $\mathrm{w}$ sprawie materiałem dowodowym $\mathrm{z}$ reguły sprowadza się do dysponowania nim. Jednakże w tym przypadku - podobnie jak świadek - nie uczestniczy bezpośrednio w procesie. Chociaż udzielana przez nią pomoc nie ma charakteru stricte merytorycznego, to jednak nie sposób odmówić takim podmiotom statusu współczynnika efektywnej ochrony sądowej.

\section{Zakończenie}

„Efektywność” w ujęciu ekonomicznym oznacza przestrzeganie zasad rachunku ekonomicznego, a zatem osiągnięcie zamierzonego zysku dzięki wyborowi najwłaściwszego wariantu do niego prowadzącego ${ }^{46}$. Jest ona możliwa do pomiaru poprzez relację nakładów, które poniosło się, do osiągniętych efektó $w^{47}$. Z kolei efektywna ochrona sądowa może być rozpatrywana na różnych płaszczyznach, w tym z uwzględnieniem kosztów sprawowania wymiaru sprawiedliwości. $\mathrm{W}$ każdym jednak wypadku w centrum zainteresowania pozostaje rezultat ochrony sądowej, a zatem - w ocenie autorki - osiągnięcie celu postępowania w najlepszy z możliwych i wydajnych sposobów.

${ }^{46}$ J. Grygierzec, Ku dobrej administracji skarbowej, w: Efektywna administracja skarbowa, red. Z. Gilowska, H. Izdebski, K. Raczkowski, t. 1, Warszawa 2007, s. 31.

${ }^{47}$ Ibidem. 
Niewątpliwie udział osób trzecich w cywilnym postępowaniu procesowym jest jednym z czynników sprzyjających zapewnieniu lepszej efektywności ochrony sądowej. Sposób, w jakim omawiane kategorie podmiotów przyczyniają się do osiągnięcia zamierzonego celu, zależne jest od przyczyny, ze względu na którą wstępują one do postępowania, a w szczególności - od rodzaju interesów prawnych, w ochronie których działają. Zazwyczaj są one tożsame $z$ interesem jednej ze stron postępowania. $\mathrm{W}$ takim przypadku, pomagając sobie i tejże stronie poprzez korzystanie $\mathrm{z}$ wielu przysługujących im uprawnień procesowych, sprzyjają sprawnemu, szybkiemu i efektywnemu przebiegowi cywilnego postępowania procesowego. Zupełnie inna jest sytuacja, gdy interesy osób trzecich są diametralnie różne od interesu danej strony postępowania. W takim przypadku - kosztem sprawności i szybkości postępowania - ustawodawca dopuszcza ich udział i, przyznając im tak daleko idący a opisany powyżej wpływ na bieg postępowania toczącego się pomiędzy innymi podmiotami, wprowadza kolejny mechanizm służący zapewnieniu efektywnego cywilnego postępowania procesowego, a tym samym - efektywnej ochrony sądowej.

\section{Bibliografia}

\section{Akty prawne}

Rozporządzenie Prezydenta Rzeczypospolitej z dnia 29 listopada 1930 r. - Kodeks postępowania cywilnego, t.j. Dz. U. z 1932 r. Nr 112, poz. 934, uwzględniające rozporządzenie Prezydenta RP z dnia 27 października 1932 r. - Prawo o sądowym postępowaniu egzekucyjnym, Dz. U. Nr 93, poz. 803.

Ustawa z dnia 17 listopada 1964 r. Kodeks postępowania cywilnego, t.j. Dz. U. z 2016 r., poz. 1822 ze zm.

Rozporządzenie Ministra Sprawiedliwości z dnia 23 grudnia 2015 r. - Regulamin urzędowania sądów powszechnych, Dz. U. poz. 2316 ze zm.

Orzecznictwo

Sądu Najwyższego

Orzeczenie Sądu Najwyższego z dnia 8 grudnia 1951 r., C 1191/51, Państwo i Prawo 1952, nr 8-9, s. 364.

Orzeczenie Sądu Najwyższego z dnia 14 listopada 1958 r., CR 193/58, NP 1960, nr 6, s. 788.

Orzeczenie Sądu Najwyższego z dnia 6 grudnia 1960 r., IV CR 73/60, Lex nr 1631929.

Uchwała Sądu Najwyższego z dnia 14 lutego 1955 r., I CO 83/54, OSNCK 1955, nr 3, poz. 52.

Uchwała Sądu Najwyższego z dnia 17 października 1995 r., III CZP 143/95, OSNC 1996, nr 2, poz. 24.

Postanowienie Sądu Najwyższego z dnia 21 maja 2009 r., I PK 10/09, Lex nr 687069.

Postanowienie Sądu Najwyższego z dnia 25 listopada 2010 r., III CZ 50/10, Lex nr 1157559.

Wyrok Sądu Najwyższego z dnia 7 lutego 1966 r., II CR 259/65, Lex nr 5938.

Wyrok Sądu Najwyższego z dnia 18 stycznia 1978 r., IV CR 463/77, OSNC 1978, nr 10, poz. 186.

Wyrok Sądu Najwyższego z dnia 7 marca 1997 r., I PKN 27/97, OSNP 1997, nr 21, poz. 422.

Wyrok Sądu Najwyższego z dnia 29 listopada 2001 r., V CKN 616/00, OSNC 2002, nr 7-8, poz. 105. 
Wyrok Sądu Najwyższego z dnia 17 kwietnia 2002 r., IV CKN 986/00, Lex nr 78368.

Wyrok Sądu Najwyższego z dnia 26 marca 2009 r., I CSK 415/08, Lex nr 577152.

Wyrok Sądu Najwyższego z dnia 14 kwietnia 2011 r., IV CSK 414/10, Lex nr 1027185.

Wyrok Sądu Najwyższego z dnia 2 marca 2016 r., V CSK 372/15, Lex nr 2023937.

\section{Sądów apelacyjnych}

Postanowienie Sądu Apelacyjnego w Krakowie z dnia 20 października 1992 r., I ACz 367/92, Lex nr 1680360.

Postanowienie Sądu Apelacyjnego w Warszawie z dnia 29 października 1996 r., I ACz 1035/96, OSA 1997, z. 5, poz. 30

Postanowienie Sądu Apelacyjnego w Krakowie z dnia 4 września 2012 r., I ACz 1232/12, Lex nr 1216300.

Wyrok Sądu Apelacyjnego w Gdańsku z dnia 7 kwietnia 1994 r., I ACr 142/94, OSA 1994, z. 6, poz. 31. Wyrok Sądu Apelacyjnego w Katowicach z dnia 3 października 2005 r., I ACa 553/05, Lex nr 164629. Wyrok Sądu Apelacyjnego w Poznaniu z dnia 18 kwietnia 2007 r., I ACa 201/07, Lex nr 446233.

Wyrok Sądu Apelacyjnego w Gdańsku z dnia 19 maja 2009 r., I ACa 392/09, POSAG 2010, nr 1, s. 26-36.

Wyrok Sądu Apelacyjnego we Wrocławiu z dnia 22 lutego 2013 r., I ACa 67/13, Lex nr 1322900.

Wyrok Sądu Apelacyjnego w Gdańsku z dnia 22 stycznia 2014 r., I ACa 318/13, Lex nr 1433773.

Wyrok Sądu Apelacyjnego w Białymstoku z dnia 25 lipca 2014 r., I ACa 236/14, Lex nr 1506665.

\section{Sądów okregowych}

Wyrok Sądu Okręgowego w Nowym Sączu z dnia 12 grudnia 2013 r., Ill Ca 780/13, Lex nr 1716548.

\section{Literatura}

Allerhand M., Interwencja uboczna przed sądem polubownym, Polski Proces Cywilny 1938, nr 21-22, s. 684-688.

Bartz A., Czy w postanowieniu, rozstrzygającem opozycję jednej ze stron przeciwko wstapieniu do sprawy interwenienta ubocznego, można także orzec o kosztach, spowodowanych opozycja?, Polski Proces Cywilny 1938, nr 16-18, s. 547-549.

Bladowski B., Metodyka pracy sędziego cywilisty, Kraków 2005.

Broniewicz W., Jakie zmiany w instytucjach interwencji ubocznej i przypozwania wprowadził nowy k.p.c. i kodeks cywilny?, Palestra 1966, nr 10, s. 19-29.

Czerwiński A., Czy przypozwany, który zgłosił interwencję uboczną, zwolniony jest od wykazania interesu prawnego we wstapieniu do sprawy?, Nowy Proces Cywilny 1933, nr 15, s. 472-474.

Dróżdż K., Inna osoba jako podmiot legitymowany do złożenia skargi na czynności komornika, w: Cechą sprawiedliwości jest nie krzywdzić ludzi. Księga pamiątkowa ku czci Zenona Knypla, Sopot 2017, s. 13-20.

Dróżdż K., Małżonek dłużnika jako osoba trzecia legitymowana do wytoczenia powództwa o zwolnienie zajętego przedmiotu od egzekucji sądowej, Przegląd Prawa Egzekucyjnego 2016, nr 5, s. 51-61.

Dróżdż K., Osoba trzecia jako podmiot uprawniony do wniesienia skargi na czynności komornika, w: Środki zaskarżenia w postępowaniu egzekucyjnym. Studia i materiały, red. J. Misztal-Konecka, Sopot 2017, s. 73-82.

Egzekucja sądowa w Polsce, kier. Z. Szczurek, Sopot 2007. 
Głodowski W., Interwencja uboczna w postępowaniu ze skargi o uchylenie wyroku sq̨du polubownego, w: Mediacja i arbitraż jako sposoby polubownego rozstrzygania sporów, red. D. Czura-Kalinowska, Poznań 2009, s. 233-245.

Gołąb A., Przypozwanie w procesie cywilnym (art. 84-85 k.p.c.), Polski Proces Cywilny 2012, nr 1, s. 99-125.

Grygierzec J., Ku dobrej administracji skarbowej, w: Efektywna administracja skarbowa, red. Z. Gilowska, H. Izdebski, K. Raczkowski, t. 1, Warszawa 2007, s. 30-49.

Ignatowicz J., Interwencja uboczna w sprawach o prawa stanu, Nowe Prawo 1959, nr 1, s. 21-33.

Jauernig O., Kilka uwag o celu procesu cywilnego, Ruch Prawniczy, Ekonomiczny i Socjologiczny 1984, z. 3, s. 61-72.

Kodeks postępowania cywilnego. Komentarz. Art. 1-366, red. H. Dolecki, T. Wiśniewski, t. 1, wyd. 2, Warszawa 2013.

Kodeks postępowania cywilnego. Komentarz. Postępowanie egzekucyjne, red. E. Ereciński, t. 4, wyd. 4, Warszawa 2012.

Kodeks postępowania cywilnego. Komentarz, red. A. Zieliński, wyd. 9, Warszawa 2017.

Kodeks postępowania cywilnego. Komentarz, red. H. Dolecki, T. Wiśniewski, t. 4, wyd. 2, Warszawa 2014.

Kodeks postępowania cywilnego. Postępowanie zabezpieczające i egzekucyjne. Komentarz, kier. Z. Szczurek, wyd. 4, Sopot 2013.

Kodeks postępowania cywilnego. Postępowanie zabezpieczajace i egzekucyjne. Komentarz, red. J. Gołaczyński, Warszawa 2012.

Kodeks postępowania cywilnego. Tom I. Komentarz. Art. 1-366, red. A. Marciniak, K. Piasecki, wyd. 7, Warszawa 2016.

Kodeks postępowania cywilnego. Tom III. Postępowanie nieprocesowe, w razie zaginięcia lub zniszczenia akt, zabezpieczające i egzekucyjne. Komentarz do artykułów 506-1088, red. A. Marciniak, K. Piasecki, t. 3, wyd. 5, Warszawa 2012.

Korzan K., Sądowe postępowanie zabezpieczające i egzekucyjne w sprawach cywilnych, Warszawa 1986. Korzonek J., Interwencja główna w k.p.c., Głos Sądownictwa 1930, nr 12, s. 805-809.

Krytyka prawa. Niezależne studia nad prawem. Własność, red. J. Jabłońska-Bonca, t. 1, Warszawa 2009.

Kulski R., Cele i funkcje postępowania cywilnego, w: Postępowanie rozpoznawcze w przyszłym Kodeksie postępowania cywilnego. Materiały Ogólnopolskiego Zjazdu Katedr i Zakładów Postępowania Cywilnego w Katowicach-Kocierzu (26-29 września 2013 r.), red. A. Torbus, K. Markiewicz, Warszawa 2014, s. 443-481.

Kunicki I., Przesłanki zgłoszenia interwencji głównej, Przegląd Sądowy 2008, nr 3, s. 49-63.

Mucha J., Zawisłość sprawy w procesie cywilnym, Warszawa 2014.

Osowy P., Interwencja główna (uwagi na temat aktualności i przydatności art. 75 KPC) - zarys problematyki, w: Ewolucja polskiego postępowania cywilnego wobec przemian politycznych, społecznych i gospodarczych, Materiały konferencyjne Ogólnopolskiego Zjazdu Katedr Postępowania Cywilnego Szczecin-Niechorze 28-30.9.2007 r., red. H. Dolecki, K. Flaga-Gieruszyńska, Warszawa 2009, s. 265-279.

Pietrzkowski H., Metodyka pracy sędziego w sprawach cywilnych, wyd. 7, Warszawa 2014.

Puternicki A., Przypozwanie, Gazeta Sądowa Warszawska 1933, nr 35, s. 545-549.

Regulamin urzędowania sądów powszechnych. Komentarz, red. M. Romańska, Warszawa 2013.

Różalska A., Powództwa przeciwegzekucyjne jako środki obrony merytorycznej dłużnika. Powództwo ekscydencyjne, Problemy Egzekucji Sądowej 1996, nr 28, s. 65-89.

Sawczuk M., O celach i funkcjach postępowania cywilnego procesowego i nieprocesowego (niespornego), w: Symbolae Vitoldo Broniewicz dedicatae. Księga pamiątkowa ku czci Witolda Broniewicza, red. A. Marciniak, Łódź 1998, s. 313-329.

Studzińska J., Participation of third parties in civil proceedings as a form of protection of their legal interest. Considerations in the context of legal security of these entities, w: The safety of the individual 
and of the group in private and public law - a collection of studies, red. E. Cała -Wacinkiewicz,

D. Wacinkiewicz, K. Flaga- Gieruszyńska, Gorzów Wielkopolski 2015, s. 71-84.

Studzińska J., Środki i skuteczność ochrony osób trzecich w postępowaniu cywilnym rozpoznawczym, w: Współczesne problemy postępowania cywilnego, red. A. Klich, K. Flaga-Gieruszyńska, Toruń 2015, s. 87-120.

Studzińska J., Znaczenie udziału osób trzecich w postępowaniu cywilnym rozpoznawczym, w: Role uczestników postępowań sądowych - wczoraj, dziś i jutro, red. D. Gil, E. Kruk, t. 2, Lublin 2015, s. 137-163.

Trammer H., Następcza bezprzedmiotowość procesu cywilnego, Kraków 1950.

Uliasz M., Kodeks postępowania cywilnego. Komentarz, wyd. 2, Warszawa 2008.

Waligórski M., Czy interwenjent samoistny ma legitymację do wniesienia skargi o wznowienie?, Polski Proces Cywilny 1935, nr 17-18, s. 563-564.

Weber A., Czy od zgłaszającego interwencję uboczna należy stronie zasq̨dzić koszty uwzględnionej opozycji?, Polski Proces Cywilny 1935, nr 5-6, s. 176-178.

Weber A., Czy sąd wydaje postanowienie o dopuszczeniu interwenienta ubocznego?, Polski Proces Cywilny 1935, nr 20, s. 631-633.

Weber A., Wpływ śmierci interwenienta ubocznego na bieg procesu, Polski Proces Cywilny 1935, nr 7-8, s. 227-231.

Wengerek E., Zedler F., Glosa do uchwały Sądu Najwyższego z dnia 7 lutego 1968 r., III CZP 89/67, OSPiKA 1970, z. 5, s. 193-197.

Wiszniewski Z., Glosa do uchwały Sądu Najwyższego z dnia 14 kwietnia 1960 r., 4 CO 3/60, Państwo i Prawo 1961, z. 2, s. 348-352.

Wolwiak I., Zarzuty osoby przypozwanej co do nieprawidłowego prowadzenia postępowania przez stronę wobec dokonanych pomiędzy nimi uzgodnień, Monitor Prawniczy 2015, nr 2, s. 1185-1191.

Zedler F., Glosa do uchwały Sądu Najwyższego z dnia 17 stycznia 2001 r., III CZP 49/00, Przegląd Sądowy 2001, nr 9, s. 126.

Zedler F., Powództwo małżonka dłużnika o zwolnienie spod egzekucji, Państwo i Prawo 1968, z. 12, s. 1013-1021.

Zedler F., Powództwo o zwolnienie od egzekucji, Warszawa 1973.

F. Zedler, Projektowane zmiany przepisów o postępowaniu egzekucyjnym, w: Reforma postępowania cywilnego w świetle projektów Komisji Kodyfikacyjnej, red. K. Markiewicz, Warszawa 2011, s. 153-169.

Zieliński M., Zawieszenie postępowania w przypadku śmierci interwenienta ubocznego. Glosa do postanowienia Sądu Apelacyjnego w Warszawie z dnia 4 sierpnia 2004 r., I ACz 969/04, Gdańskie Studia Prawnicze 2014, nr 1, s. 85-93.

Żywicki W. i in., Adwokatura jako współczynnik wymiaru sprawiedliwości, Palestra 1959, nr 7-8, s. 19-38.

\section{Streszczenie}

W niniejszym opracowaniu autorka dąży do wykazania, że udział osób trzecich w cywilnym postępowaniu procesowym stanowi jeden z czynników mających znaczący wpływ na zapewnienie efektywnej ochrony sądowej. Ten wpływ w przypadku udziału omawianej kategorii podmiotów może być realizowany poprzez udzielenie pomocy jednej ze stron procesu. Jednakże może on przybrać zdecydowanie bardziej znaczący charakter, gdy udział osób trzecich w postępowaniu ma na celu przeciwdziałanie pewnym negatywnym zjawiskom procesowym, które mogłyby doprowadzić do wypaczenia całego cywilnego postępowania procesowego. W kolejnych fragmentach pracy omawiane są poszczególne instytucje procesowe, takie jak chociażby interwencja uboczna, przypozwanie, interwencja główna czy powództwo z art. 841 K.p.c., które stanowią narzędzia, za pomocą których 
istnieje możność udzielenia wsparcia przez osoby trzecie w realizacji celu cywilnego postępowania procesowego w najlepszy z możliwych sposobów.

Słowa kluczowe: osoba trzecia, efektywność, ochrona sądowa, interwencja główna, interwencja uboczna, przypozwanie, powództwo ekscydencyjne, postępowanie dowodowe.

\section{Third persons as a factor for efficient court protection in civil litigation proceedings}

\section{Summary}

In the present work the author leads to demonstration that participation of third parties in civil litigation proceedings forms one of the factors that significantly influence the securing of efficient court protection. This influence in case of participation of the discussed category of subjects can be completed exclusively by providing aid to one of the parties of the proceedings. Nevertheless it can adopt a significantly more meaningful character, when the participation of third parties in proceedings leads to counteracting negative proceeding phenomena, that could lead to distortion of the whole civil law court proceedings. The subsequent fragments of work discuss the respective procedural institutions, such as e.g. secondary intervention, third party action, main intervention or action of art. 841 of the Polish Code of civil proceedings that form the tools that allow support of third person in accomplishment of the aims of civil court proceedings in the best way possible.

Keywords: third person, efficiency, court protection, main intervention, secondary intervention, bringing a third party action, interpleader claim, evidentiary hearing. 